DOI 10.18551/rjoas.2019-10.31

\title{
ROLE OF TRADITIONAL VILLAGE AND ENVIRONMENTAL CONDITIONS ON THE EDUCATION OF CHILDREN
}

\author{
Serinah I Wayan*, Utama I Made Suyana \\ Faculty of Economics and Business, University of Udayana, Bali, Indonesia \\ *E-mail: wasarbali@yahoo.com
}

\begin{abstract}
Development programs are carried out to achieve welfare of community. Human Development Index (HDI), as one measure of welfare, places the education sector as one aspect other than the economic sector (income per capita), because the level of education influences the level of income. The level of education will be even higher if there is an increase in access to education, namely decreasing dropout rates and increasing school-age children who continue their education up to secondary education according to the 12-year compulsory education program. Children's education level is influenced by family environment, school environment and community environment. Traditional villages in Bali with very strong social capital has a form of traditional customs named awig-awig and pararem - reciprocal relations such as mutual cooperation, family ties, and community trusts is still very strong role in improving children's education. In the implementation of educational development, synergy between the local government and traditional villages is needed so that the level of education increases and so does welfare of the community.
\end{abstract}

\section{KEY WORDS}

Welfare, education, environment, social capital, customary villages.

Development basically aims to accelerate the achievement of people's welfare. Welfare is the ultimate goal of all development activities, both national and regional scale. Development cannot be said to be successful if it is unable to make the community more prosperous. In line with the statement of Midgley (2000) which defines social welfare as "... a condition or state of human well-being", the meaning of prosperity will occur if the conditions in human life are safe and happy where basic needs including food, clothing, board, the need for nutrition, health, education, or income can be met and when people get protection from the main risks that threaten their lives. A prosperous society covers all aspects of life: ideology, politics, economy, social, culture, as well as order and security. The size of prosperity is not only measured from the economic aspect (income), but also social aspects. The United Nations Development Program (UNDP) in 1990 began to use the Human Development Index (HDI) as a measure of development achievement by combining economic aspects (income per capita) with social aspects (education level and health status). Todaro (2004), with the concept of HDI allows countries to measure their development performance both in relative and absolute terms, because HDI combines social data and economic data. The use of educational achievement data in HDI is an emphasis on the importance of human resource development to accelerate the achievement of people's welfare. The education indicators in HDI are formed from long school expectations (HLS) and average length of schooling (RLS). Gilley and Eggland (1996), human development refers to the advancement of knowledge, competence and improvement of the behavior of human resources themselves, both for individual and organizational interests. Human resources is one of the potentials that needs to be explored and developed in order to develop the capacity and capabilities of each individual to achieve the welfare of individuals, families, communities and the nation. Todaro (1983), the factor of production of capital and natural resources is a passive factor of production, while the factor of production of labor (human) is an active factor of production that can raise capital, exploit natural resources, build social, economic and political organizations and carry out national development . It is very clear, quality human resources that will be able to accelerate the achievement of public welfare, so 
that education development is a priority. The World Bank also states that human capital is the most important factor and plays a very dominant role in encouraging community progress. Human capital investment is reflected in the Human Capital Index ( $\mathrm{HCl})$ by combining several components, namely the probability of living to the age of 5 years (survival), the quality and quantity of education, and health (Wira Sakti, 2018).

Competent human development can only be done through education, because education is the path to quality human resources whose role is to educate and advance people's lives. One of the problems addressed is reducing school dropout rates and encouraging school-age children to continue their education up to secondary education. Based on the above background, in order to improve children's education by reducing dropout rates and encourage school-age children to continue their education until secondary education, this paper will examine from the perspective of the role of Indigenous Villages and the environment of indigenous peoples in improving children's education, so that it is simultaneously effect on improving the general welfare of the community.

\section{RESULTS AND DISCUSSION}

The definition of education according to the National Education System Law is a conscious and planned effort to create an atmosphere of learning so that students actively develop their potential to have spiritual spiritual strength, self-control, personality, intelligence, social attitudes and skills needed by themselves, the community, the nation and country. From a different perspective, education is defined as the process of learning the knowledge, skills and habits of a group of people who are passed down from one generation to the next through teaching, training, or research (wikipedia.org, 2019). Chiuri \& Kiumi (2005) state the World through formal education is the main highway where young people are socialized into social norms and labor market requirements, to improve personal and household welfare. This statement is supported by Blondal (2014) that in our modern knowledge-based society, with mass education and increasing dependence on highly skilled workforce, young people who do not complete senior secondary education, will face more disadvantages than before. The achievement of welfare is strongly influenced by the achievement of formal education in increasing competence to compete in the world of work in increasing income as one of the indicators of welfare. Quinn \& Rubb (2006) states, education is one of the needs of modern society's access to wealth and social welfare. Education contributes to improving and developing the social and economic status of individuals and building a vibrant community and a strong nation. According to Kolle in Bintarto (1989) states that in measuring a person's welfare can be done by using welfare indicators, one of which is through the achievement of the level of education. The higher the level of someone's education, the level of welfare will increase.

Based on the above understanding, education is a process that must be carried out to be able to improve knowledge, skills and behavior patterns that are characterized and have integrity to achieve prosperity. However, in its implementation there are still various obstacles and obstacles such as dropping out of school or school-age children not continuing their education until the secondary education level in accordance with the 12-year compulsory education program set by the government. According to Rumberger (1987), school dropout is defined as "someone who has not graduated from, or is not currently enrolled in full time, state approved education program". Furthermore Djumhur and Surya (1975), Rahman (1998), Frances Hunt (2008), Ahmad (2011), Gunawan (2019), generally stated that dropping out of school is a condition of school-age children who stop or quit the learning process in school either in the middle or in a certain level, in the final semester of a certain level of education, or stopping between levels ie not continuing education to a higher level of education in accordance with the regulations set by the government. In this context, what is meant by the provisions stipulated by the government is compulsory education for 12 years to the level of secondary education.

Various studies and research that have been done relating to the factors causing dropouts, Rumberger \& Larson (1998), Goksen, et-all (2006), Sirin et-all (2009), Krisna Dewi, 
et-al (2013), and Ajis (2013), Farah (2014), Mishra \& Azeez (2014), Sutiasnah (2015), Fatimah (2015), Rasmy et-all (2017), Khan et-all (2017) in general can be concluded that dropouts occur because of economic factors, non-economic factors, factors that originate from students themselves and factors from outside themselves students.

Efforts to overcome the occurrence of school dropouts and implement 9-year compulsory education. BOS for high school and vocational school levels is only programmed starting in 2014 as a follow-up to Minister of Education and Culture Regulation Number 80 of 2013 concerning Universal Secondary Education. Furthermore, through Presidential Instruction No. 7 of 2014 it has been instructed to the Ministries / Institutions and Local Governments to implement the Productive Family Program, one of which is the Smart Indonesia Program (PIP) listed in Nawa Cita which is a 12 year compulsory education. The purpose of implementing PIP is that all school-age children receive educational services to graduate from the secondary education unit and prevent students from dropping out. To realize this, programs are needed that can remove barriers to children, especially in economic terms to increase the average length of schooling to 12 years or the equivalent of secondary education (P.SMK Kemdikbud, 2016). Obviously the existence of children dropping out of school and not continuing still and continues to occur, so it takes real effort by the government to synergize with stakeholders (steakholders) and the community. Synergy by involving the community really needs to be done, because various analyze conducted, found that the community environment is very influential and has a role in achieving the level of children's education.

Abu Ahmadi (2009), Family is the smallest community unit which is at the same time a small group in the community. Parents are the first social institution that colors the child's personality, this is because in the family will be instilled positive values and norms of life that will eventually be used by their children as a guide in society and education. In a family environment, parents are first and foremost who provide education to children from birth. In directing and encouraging that their children have a better and prosperous future, the parents' pran in education in this paper will refer to the Theory of Planed Behavior from Ajzen's in Alghazo (2013) that the theory of planned behavior is "a theory designed to predict and explain human behavior in specific contexts". According to the theory of planned behavior, one should understand the reasons that lead to intentions in order to be able to predict future involvement in a behavior. In this kointes, the theory of planned behavior is directed to understand the reasons for the involvement of parents to predict the future of their children through education.

Based on the theory of planned behavior (Ajzen, 1991), Alghazo (2013) in his study developed Theoretical Models of Parental Involvement, to help explain the intentions and objectives of parents involved in children's education and the factors that influence the level of parental involvement. The schema of planned behavior behavior theory related to parental involvement in children's education and its relationship to family socioeconomic factors in educational attainment and educational attainment is illustrated in the following figure.

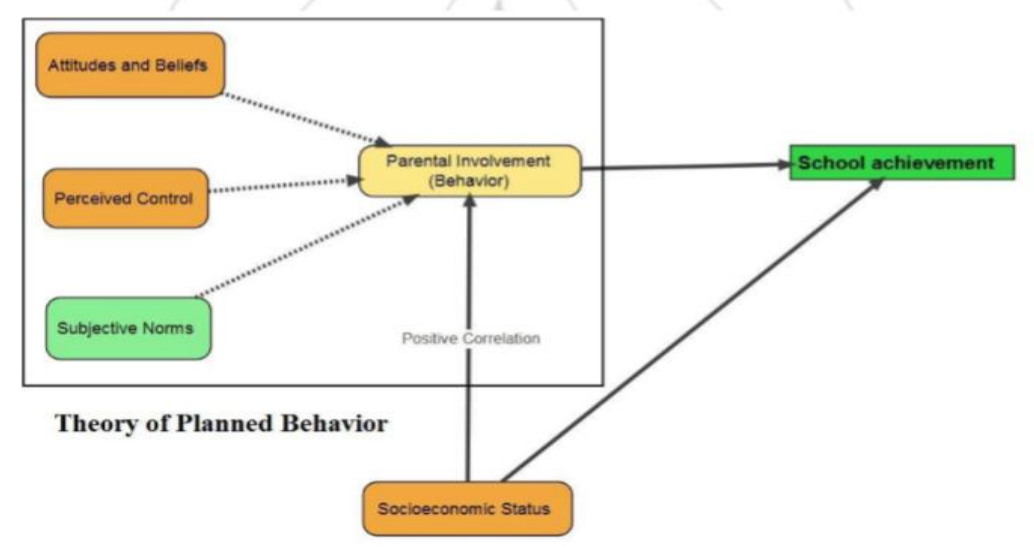

Figure 1 - Theoretical Models of Parental Involvement 
Various studies show that children's education level is also influenced by the family's socioeconomic status. Efforts must be made to improve community education by minimizing socio-economic influence by increasing parental involvement in children's education, so that education disparities in the community do not occur. Alghazo's paper (2013) recommends that parental involvement be emphasized as a tool to match the influence of socioeconomic status on student achievement and the gap in children's education levels in the community or regional environment. If schools can increase the level of parental involvement in their children's education, then the negative effects of families with low socioeconomic status can be reduced specifically in terms of children's achievement and motivation to continue their education to a higher level.

Educational development that is carried out is one form of fulfilling the basic rights of children, namely the right to grow and develop and the needs of children that must be met, namely learning needs. The fulfillment process will not be separated from the influence of its environment, especially the family environment, community environment and the school environment through the process of education both informal education, formal education and non-formal education. Mishra \& Azeez (2014) stated that family is the most influential agent among different social factors that significantly influences the growth and development of any child. It was further explained that the family environment, economic status, social status, and parental education influence the child's developmental milestones. Education is an important dimension of child development and is an important driving force in the process of socialization and personality formation.

\section{BACKGROUND ENGAGEMENT EDUCATIONAL PERFORMANCE}

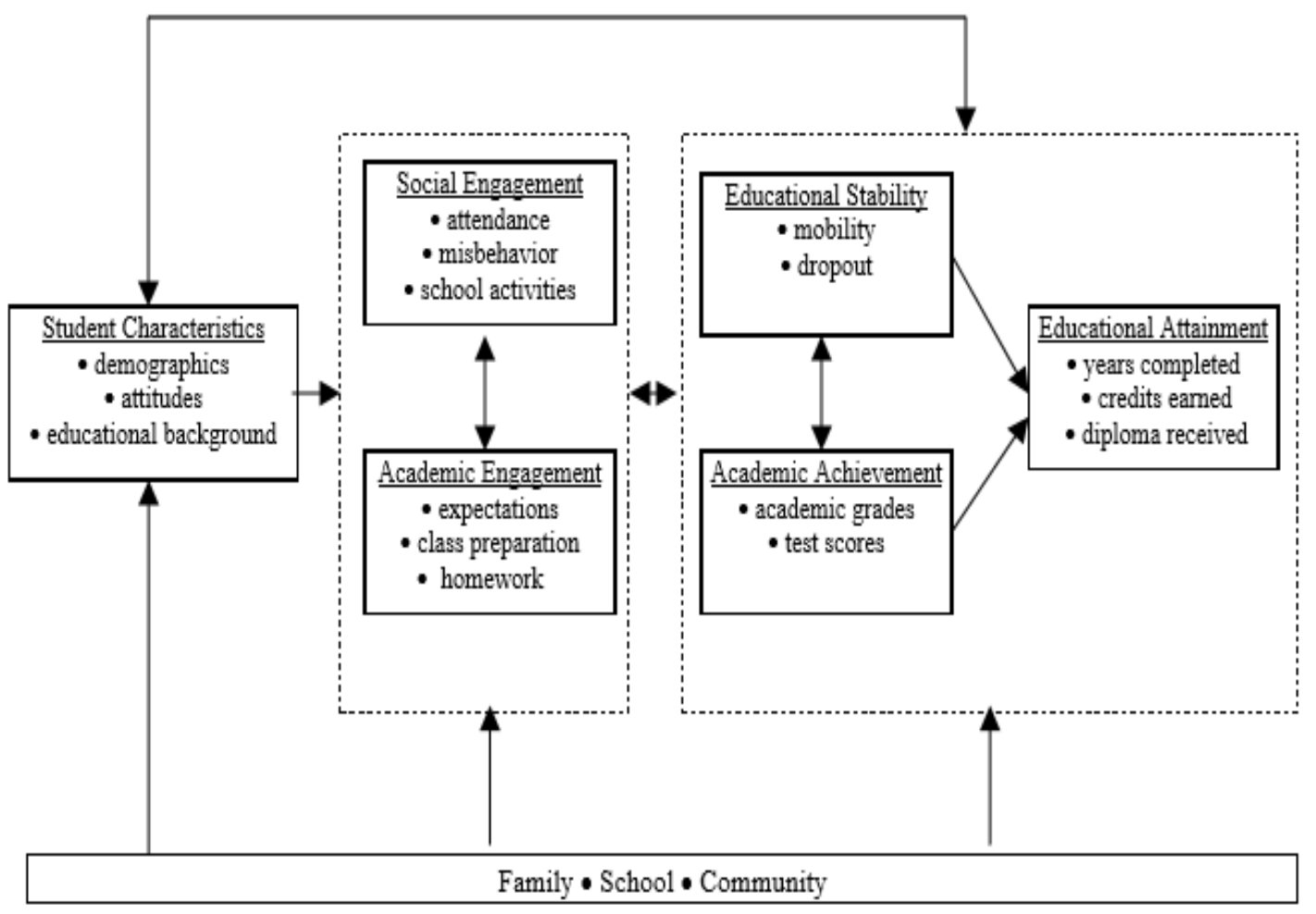

Figure 2 - Conceptual Framework for Studying Student Educational Performance (Source: Rumberger \& Larson, 1998)

Creating an environment for having quality education is the moral responsibility of the family and community because education is also an important factor for empowerment and socio-economic development. Maggi et al (2005) also states, by school age, development has been influenced by factors at three levels of society: family, neighborhood / village, and the broader societal level. It is clearly stated that the family environment, the community and 
the wider community or village have an influence on school-age children in pursuing their education. Continuation of childhood is adolescence with various problems. It also needs to be a concern in improving access and quality of education, so that adolescents avoid dropping out of school. Karaman (2007) argues that, "adolescence is a period that bridges childhood and adulthood world, where there is an increased number of risks". In the period of time between childhoods to the adult world is called adolescence, where during adolescence there will be an increase in the number of risks and many challenges. Associated with this adolescence, Zarrett \& Eccles, (2006) stated that when they pass through adolescence, they will face many challenges, including conflicts with their parents, because of the increase: a sense of mastery, the search for identity, the development of autonomy and building niches. for themselves in society. Furthermore, if conflict is poorly managed it is likely to be a factor causing students to drop out of school (Doll, Eslami \& Walters, 2013).

Furthermore, Rumberger \& Larson Research (1998) revealed the relationship between educational performance with individual students, the school environment, family conditions and environmental conditions as outlined in the "Conceptual Framework for Studying Student Educational Performance". Within the framework of this concept, educational performance will be influenced by the child's individual background as seen from the perspective of gender education, attitudes or perceptions about education and educational background of parents. This background directly affects the social conditions in schools, and the academic condition of students. The framework for the concept of educational attainment is described in Figure 2.

The first framework is seen from the background (perspective) of individual students who focus on student characteristics namely their grades, attitudes and behavior, and how these characteristics contribute to their decision to quit school. Dropouts occur due to individual backgrounds and student characteristics, basically there are two dimensions of involvement, namely academic involvement or learning involvement and social involvement. This involvement will be reflected in the attitudes and behavior of students who are associated with formal aspects of the school such as behavior in the classroom and its activities at school, and informal aspects seen from relationships with peers. Both dimension of this involvement both academic involvement and social involvement can influence the decision to stay in school or quit school. Dropping out of school is one aspect of the dimensions of educational achievement in addition to aspects of academic achievement, aspects of educational stability (still in school) and aspects of educational attainment or completion of education. From this framework it can be seen that educational achievement is influenced by educational stability and academic achievement. Students, who are distracted, will drop out of school, transfer schools or are less likely to graduate completing their education. Furthermore, it can be concluded that student involvement and student educational achievement is influenced by the background of students before entering school and there is a reciprocal relationship between the factors of individual attitudes, social relations, and experiences in the school environment towards the achievement of education whether students will drop out of school or be able to complete their education. So the family environment, school environment and the surrounding community contribute to the attainment of children's education level.

In line with the above work scheme, Santrock (2010), states, the ecological system theory developed by Urie Bronfenbrenner, the main focus is on the social context in which children live and those that influence children's development. In ecological theory, human development is the result of interactions or transactions between internal forces and external forces. Interaction is the basis for human development. Interaction is defined as an activity of mutual influence between internal forces (organisms with various attributes) and external forces (environment: physical, psychological, and social). The form of interaction that occurs is likely that individuals are influenced by the environment, the environment is influenced by individuals, or individuals and the environment is constantly interacting with each other so that it changes. In relation to children's education and preparing children for a better and prosperous future, the relationship between the family environment and children's education is much related. Pelto, et al (1999) states "Families are the first environments with children 
interacting from birth. They are critically important in providing children with stimulation, support and nurturance". It was explained that the family was the first environment that interacted with children from birth. The existence of a family is very important in providing stimulation, support and care for children towards the development of the next life. Furthermore, Bronfenbrenner (1986), states that the characteristics of the family environment can affect children's development both positively and negatively, as risk and protection factors. With regard to family relationships with children, the quality of this relationship is influenced by the resources that the family must devote to raising children or in other words is strongly influenced by family income, their parenting style, and their tendency to provide a conducive and responsive environment. This quality is also strongly influenced by the level of parental education, family education level and community education level. In human development, the concept of the environment is something that is inherent in individuals. Every time an individual can not be separated from his environment, even continue to interact continuously (intensive and continuous) in a dynamic process and influence each other (Somad, 2013).

Interaction between individuals with the environment is seen as positive if the interaction takes place in a process that is mutually beneficial and mutual. Functional means that the environment is able to provide facilities, opportunities or opportunities, stimulation or encouragement, and exemplary for the development of the individual's nature, potential, or meaningful personal competence. Ahmadi and Uhbiyati (2001), Association is direct contact between one individual and another individual. The social environment is a place for the development of behavior towards existing habits in the environment. A bad social environment will negatively affect the development of one's soul. If bad behavior is received by children in interactions in society, then the behavior will become something that is normal for him, so that it can influence someone to violate the norms that exist in society. Sampson (1992) also explains, that peer relationship models will provide a theoretical basis for studying the mechanism of environmental change processes that occur and determine the different levels between individuals, families, schools, peers, and the community where the change process can take place. This statement is in support of Shaw \& McKay's (1942) social disorganization theory: social disorganization theory states that environmental structural factors such as poverty, residence instability, single parenthood, and ethnic heterogeneity are very important in explaining behavior through their ability to frustrate or promote environmental organizations (formal and informal institutions) in an effort to maintain public order.

Furthermore, aspects of the social environment of adolescents according to Hadi (2005) include: First, the Family Environment. The family environment which is the first environment associated with children is their parents, siblings, or maybe close relatives who live together. The family environment is a miniature of the community and its life, so the family pattern will give the child a view of life in the community. Second, the School Environment. School is a place where children carry out directed learning activities and are well programmed. School association means all activities between teachers and students which include: learning activities, social interactions, and social communication between school members. So it can be concluded that school association is an environment where teachers and students conduct teaching and learning activities as well as social interactions and personal communication between school residents, and Third, Community Environment. Community environment is the environment around individuals to interact from the community environment that will affect the growth and development of adolescents such as community life patterns, socializing friends, development of information technology and mass media.

Kitavi (2005) in his thesis states that the influence of parents and community are the two most important components in the home background that affect learning and performance in school. He argues that a good home environment complements the efforts of teachers in schools and in related studies of UNESCO (2001), observing that quality education requires strong support from student homes. Rasmy, et-al (2017), states that the factors that cause failure to complete education in secondary school or drop out are family 
conditions, family structure, number of dependents in the family, family income, parent education, family character, environmental conditions, geographical location, perspective of parent education and expectations of the child himself. Likewise, what Rumberger (2001) stated in addition to families and schools, communities and peer groups can influence students with draw from school. There is at least some empirical evidence that differences in neighborhood characteristics can help explain differences in dropout rates among communities apart from the influence of families. The family environment, the school environment, the community (community / village), peer groups influence the attainment of children's educational level. The different characteristics of the community (village) will be able to clarify differences in the level of dropout and the factors causing it.

From several theories and empirical studies conducted, it can be concluded that the family environment, school environment and education level make important contributions in life and well-being. Children's educational performance is influenced by the school environment, so that in this cycle the management of educational programs must be implemented well, effectively, efficiently and transparently and really directed to improve access and quality of education to realize community welfare.

The influence of the community environment on achieving educational levels is very significant. Specifically for Bali, the role of Indigenous Villages in Bali will be examined in increasing the level of education of children, especially reducing school dropouts and encouraging school-age children to continue their education at least until secondary education as the implementation of a 12-year compulsory education program.

Before entering the main discussion of the role of Indigenous Villages in children's education, it will be discussed related to the existence of Indigenous Villages in Bali. Customary village is a unit of customary law community that historically has territorial boundaries and cultural identity that is formed based on territorial authority that regulates and manages the interests of village communities based on original rights (Asshiddiqie, 2014). This is an implementation of the Elucidation of Article 18 of the 1945 Constitution states:

"In the territory of Indonesia there are approximately 250 zelfbesturende landchappen (swapraja areas) and volksgetneenschappen, such as villages in Java and Bali, nageri in Minangkabau, hamlets and clans in Palembang and so on. These regions have an original arrangement and can therefore be considered as special regions".

In Law Number 6 of 2014 concerning Villages, it is stated that the Village is a village and a customary village or what is referred to by another name, hereinafter referred to as Village, is a legal community unit that has the authority to control and manage government affairs, the interests of the local community. based on community initiatives, original rights, and / or traditional rights recognized and respected in the government system of the Unitary Republic of Indonesia. Furthermore, in Article 18 regarding Village Authority, it is also mentioned that the Village's authority includes the authority in the field of Village Administration, the implementation of Village Development, Village community development, and the empowerment of the Village community based on community initiatives, rights of origin, and village customs. Structuring of Customary Villages, regulated in article 96 which states that the Government, Provincial Regional Governments, and Regency / City Governments undertake the structuring of customary law communities and are designated as Customary Villages. One of the requirements for structuring the Customary Village is the existence of customary legal norms. The authority granted to the Indigenous Village, specifically in community empowerment, is intended so that the Indigenous Village jointly plays a role and is involved in development to improve the welfare of the community. Associated with efforts to empower communities and the existence of customary law products that have local wisdom values that are highly adhered to by indigenous villagers, the development program which is a priority of the government if synergized with policies and customary village legal products in implementing development programs for community welfare will be more effective in its achievement. According to Abdurrahman \& Wentzel (1997) that "indigenous peoples live with social life patterns in which the law operates and at the same time is the result of the social process which is the source of the law". The existence of indigenous peoples to grow and live from a real life needs, way of life and 
outlook on life as a whole is a socio-cultural characteristic of the local community with their respective customary laws, so that each customary village has a special characteristic with its autonomous rights. Indigenous villages as active cultural heritage and still exist today (living heritage) are Indonesia's cultural riches. The existence of a traditional village as a preserver as well as an active actor of local wisdom has the potential to maintain cultural identity and build awareness of cultural diversity in Indonesia. Thus, customary villages are part of the nation's wealth that must be preserved and one of the preservation efforts is to carry out revitalization (Directorate General of Culture, 2018).

Based on the explanation above, the adat community is a social unit that has formal organizational requirements to be able to stand on its own, namely to have legal unity, unity of authority and environmental unity based on the common right of belief and trust in God, behavior patterns of community members and regional governance territorial and environmental consisting of land, water, nature and all its contents as well as supporting facilities that are regulated in the customary law structure with the characteristics of communal life, where mutual cooperation, please help, one sense as part of community life. Customary village as a community with a group of people as indigenous villagers in certain territorial areas that have high kinship ties and genealogical attachment. Customary villages with autonomous structures and governance with special characteristics in each customary village autonomously, the implementation of the community's life management and the implementation of development are also carried out specifically with specific written and unwritten norms and rules that apply in the customary village and obeyed by all its citizens.

Customary village life arrangements as above, will give birth to a pattern of uniformity in the activities of its citizens both economic, social, cultural, political activities, including the perception of the importance of education for children. Uniformity of life patterns and adherence to customary norms and rules, lead to the development of local wisdom that is still maintained and passed down, as manifested in the form of knowledge systems, beliefs, arts, morals, laws, customs, and various abilities and habits in daily life days that have great value and adhiluhung. The development process carried out by the government in an effort to improve the welfare of the community must always understand and pay attention to the socio-cultural values of indigenous peoples, because the social culture of indigenous peoples is very much related to their beliefs and religions. The process and implementation of development really require participation from the community and if it is not in accordance with the socio-cultural values of the community, the implementation of the development program will not be carried out properly and will even be rejected by the community. Nasrul (2013) states, things that need to be known, considered and understood in village / nagari development in West Sumatra are the various specialties that exist in rural communities so that development programs can be implemented and run as expected. The specificities of the villages in question include among others that the village community is relatively very strong in attachment to old values such as culture / customs and religion. Old values or commonly referred to as traditional culture itself according to Dove (1985) are very and always related to the process of economic, social and political change of the community in the place where traditional culture is attached. Local institutions / organizations are an important element in village development. Without local institutions / institutions, coupled with bureaucracy and participants, infrastructure cannot be built or maintained.

Traditional villages in Bali which are traditional social institutions are social groupings based on territorial unity marked that they reside in the same area, have duties in mutual cooperation activities and carry out the tasks of Pasukaduka. There are also other groupings based on genealogical things such as what is called a single kawitan, single sanggah, social grouping called sisya based on who is made the leader in a religious ceremony. The traditional institution is very functional for the preservation and harmonization of Balinese culture which is built based on the foundation Tri Hita Karana's conception (Gede At-all, 2016). The elements of Tri Hita Karana are devils, pawongan and palemahan. These three elements are a form of relationship harmonization, namely: Parahyangan is the harmony of human relations with God; Pawongan is harmony between humans and fellow human beings; and Weakening is harmony between humans and nature. Every traditional village in 
Bali has these three elements of Tri Hita Karana. The devil element is manifested through bhakti worship (worship) in Kahyangan Tiga Temple, which is manifested in the power of God as the creator in the Village Temple, the power of God as the preserver in Puseh Temple, and the power of God as the fuser in Pura Dalem. These three harmonious relationships are the spirits of Balinese people, especially those who are Hindus, do their daily lives with an atmosphere of peace, security, security and prosperity, both physically and mentally. The existences of Indigenous Villages in Bali in its implementation are in line with and in line with the Dinas Desa, and even complement each other to realize community welfare. The existence and position of the Customary Villages in Bali has been strengthened by the Regional Regulations of the Province of Bali, most recently by the Regional Regulations of the Province of Bali Number 4 of 2019 concerning Customary Villages in Bali.

Regional Regulation (Perda) of the Province of Bali Number 4 of 2019 concerning the Customary Villages in Bali, explained that the Customary Villages are a customary law community unit in Bali that has territory, position, original structure, traditional rights, own assets, traditions, manners the association of community life for generations in the bonds of the holy place (the heaven of three or the village of heaven), the duties and authorities as well as the right to regulate and manage their own households. Furthermore, the administration of the Adat Village is the administration of community life in the Adat Village which is related to the Parahyangan, Pawongan, and Palemahan that are recognized and respected in the government system of the Unitary State of the Republic of Indonesia. While Tri Hita Karana is the three causes of happiness, namely a balanced or harmonious life attitude between serving God, serving fellow human beings, and loving the environment based on sacred sacrifice (yadnya).

The unity of customary law communities in Bali is a religious social bond. To be qualified as a Customary Village, one must meet various socio-cultural religious requirements, including: having one regional unit (Wewidangan, Palemahan), one community unit (Krama, Pawongan), one traditional government unit, and being bound in one cosmological unit Kahyangan Desa or Tri Kahyangan / Kahyangan Tiga (Explanation of Bali Province Regulation Number 4 of 2019). The basis for implementing Yadnya is Sad Kerthi is an effort to purify the soul (atma kerthi), preserve forests (wana kerthi) and lakes (danu kerthi) as sources of clean water, seas and beaches (segara kerthi), social harmony and dynamic nature (universe) kerthi), and building the quality of human resources (jana kerthi).

Customary villages play a very important role in managing and fostering the lives of indigenous village communities, including in development carried out by the government, provincial and district / city governments to improve community welfare. In Sudibia, et al (2016), it is mentioned that customary villages have autonomous characteristics in various fields such as organization, economy, social culture, and security arrangements. In fact in the Province of Bali there are two types of villages that go hand in hand and are complementary namely the official village and the adat village. The service village is a government unit one level below the sub-district that carries out community empowerment and government administration services. Meanwhile, traditional villages are Hinduistic religious social institutions, or Hindu social and religious institutions at the village level whose function is to organize, regulate and foster the social life of their village residents, which includes tattwa, religious decency, and religious ceremonies (Surpha, 2004).

The existence of Indigenous Villages with the authority they have and the role that is carried out in social life, so if it is associated with social capital theory, it is very appropriate and a major part in improving children's education. According to Fukuyama (2001), social capital is defined as a set of informal values and norms that are shared between members of a group of people that enable cooperation between them. The three main elements of social capital are trust (trust), reciprocal (reciprocity), and social interaction. Furthermore, according to Woolcock, 1998 in Voydanoff (2001), social capital is information, trust, and norms of reciprocity inherent in social networks. Meanwhile, Putnam (1995) states "Social capital is a feature of social life-networks, norms, and trusts that enables participants to act together more effectively to pursue shared objectives". The norms and reciprocal networks that make collective action possible are themselves contingent on an existing foundation of social trust 
and solidarity (Putnam, 1995). With trust, the network and the rules (norms) that exist in the community will occur in an effective coordinated action in achieving common goals. Of the three elements of social capital above, trust (trust) can encourage someone to cooperate with others to bring about productive activities or joint actions. Trust is a product of social norms and order of life which is very important which then raises social capital. Furthermore reciprocal (reciprocity), can be found in the form of cooperation, mutual giving, receiving and helping each other that can arise from social interaction. While social interaction is an increasingly broad relationship that will become a kind of social network that is increasingly widespread both within the scope of trust and the scope of reciprocal relationships in society.

Coleman (1988), Social capital can exist in three main forms: as an obligation and an expectation, as an information channel, and as a social norm. As part of social capital, social networks provide opportunities for information exchange. However, the quality of information exchange is largely based on the functional components of social capital, trust and norms. A high level of trust between individuals facilitates the exchange of more knowledge, while norms govern and influence the behavior associated with this exchange. In the 1980s James Coleman developed the concept of social capital to conceptualize social patterns and processes that contribute to ethnic disparities in student achievement. He argues that educational expectations, norms, and obligations that exist in the family or community are important social capital that can influence the level of parental involvement and investment, which in turn influences academic success (Coleman, 1988). Social capital has three typologies, as well as an expression of energy or power that can optimize the potential of other capital. The typology of social capital includes social capital as an adhesive / binding, social capital as a buffer / bridge and social capital as a connection or access. In the context of empowering social capital into basic capital that makes other capital effective such as human capital, environmental capital, financial capital (Syahra, 2003).

In the context of education, social capital is the relationship between students, families, communities, and teachers available to support and motivate students towards academic success and educational attainment. Social capital in the form of parental expectations, obligations, and social networks that exist in families, schools, and communities is important for student success. This variation in academic success can be related to the expectations and obligations of parents to educate their children; to the network and connections between families served by the school; with a disciplined and academic climate in schools; and with cultural norms and values in society that encourage children's education.

In Uphoff's view in Soetomo (2006), social capital can be seen in two categories, structural and cognitive phenomena. The structural category is social capital associated with several forms of social organization specifically roles, rules, precedents and procedures that can form a broad network for cooperation in the form of mutually beneficial joint actions. Social capital in the cognitive category is derived from mental processes and results of thinking that are reinforced by culture and ideology, especially norms, values, attitudes, beliefs that contribute to the growth of cooperation, especially in the form of mutually beneficial joint actions.

In relation to the existence of social capital in indigenous communities in Bali, the role of traditional villages in Balinese life management is very important. Conclusion Suarmanayasa, et al (2016) Effect of Social Capital, Community Participation, and Performance of Indigenous Community Financial Institutions for Rural Development in the Province of Bali, states that social capital has a significant direct and positive effect on Public Participation. This means that perceptual Social Capital can improve the quality of participation of rural communities in the province of Bali. Furthermore Sudibia, et al (2016), Research on Empowerment of Indigenous Village Communities in Supporting Village Credit Institutions (LPD) in Bali Province, found that social capital had a positive and significant effect on the existence of LPD in the Province of Bali. These results indicate that the social capital seen from the LPD's network, the trust of the village manners to the LPD, the norms adopted by the village manners associated with the existence of the LPD, and the community's expectation for the development of the LPD, which runs well in the Pekraman 
village environment, can strengthen the existence of the LPD as the village financial institution in the province of Bali.

Research conducted by Romero (2010) reveals the process of education of indigenous peoples starting from children's knowledge about living peacefully and playing an active role in the community in accordance with the social environment, culture, behavioral norms and rules of life according to values and belief systems, moral teachings, and procedures that guide discourse and interaction in the community. In addition, norms related to the spiritual or religious world were also instilled during the early years at home and family which strengthened cultural identity, personality, a sense of responsibility towards others, spiritual and moral values for dealing with outsiders. There is ample evidence of the success of the educational process in indigenous peoples around the world, and educational success must begin with a period of independent learning from the family and community level, where the educational process must be in accordance with the perspective of cultural values, community trust (Romero, 2010). Tobin (2005) states that educational leaders and practitioners will look for better ways to educate their children that will be applied in schools, related to the learning process or curriculum and instructional goals of learning from educators or instructors. The learning process will run well when they believe that the curriculum is a logical extension of the socialization process in accordance with the culture and beliefs of the community or does not conflict with their beliefs.

An indigenous family and community is the first party to decide what and how education is desired for their children starting from early childhood education, including its subsequent growth and development. The initial learning experiences they gained in their homes, families and communities, including what, how, why and when they learned were socialized through oral traditions. This knowledge is the basis for children to continue their education in school or other learning places (Romero, 2010).

Smith, et al (1992) results of his research found that an analysis of the behavior of public high school dropouts is influenced by social capital in society. Differences in community social capital can make a substantial difference in an individual's tendency to quit and leave school. The role of Indigenous Villages in education as revealed by Sumunar, et al (2017) that to improve development in all fields, education has a major role, because through education, human resources can be explored as well as development people can be increased. Principled from the statement of the wise, that ignorance is the culprit of poverty and poverty, the village of Tenganan custom gives priority to improving quality in education, health and poverty alleviation. Desa Adat participates and contributes through the School Committee.

Paying attention to the role and function of traditional villages in Bali in empowering people who have autonomy in regulating community life arrangements based on traditional village awig-awig and pararem customary villages, the implementation of development programs related to the process towards community welfare especially the implementation of compulsory education basic education and 12-year compulsory education will be carried out in synergy with the central, provincial and district / city governments by regulating it in pararem adat villages. Rindawan (2017) The condition of Indigenous Villages in Bali has been very good and organized because the indigenous people in Bali have been arranged very neatly since Empu Kuturan / Empu Rajakerta, especially in this modern era, it has always improved itself since the New Order era through the Village competition, Desa Adat has never left to clean up. Strictly the concept of managing the Customary Villages in Bali adheres to the concept of Tri Hita Karana, so that the Customary Dasa in Bali is arranged neatly with complete regulations (Awig-Awig Customary Villages). Regulations that are specific but do not conflict with norms of truth and public interest and do not conflict with higher regulations can preserve and preserve Balinese customs and culture to date.

The number of Adat Villages in Bali is 1,495 Adat Villages that have a legal system and autonomous government. The way of life of the people is regulated by Awig-Awig whose implementation is outlined in pararem. Specifically, in building the quality of human resources or jana kerthi, education is a priority program to be implemented by developing pasraman education and encouraging and facilitating school-age customary villagers to improve access 
and quality of education in realizing quality Balinese human resources. The existence of a Customary Village in Bali is a bastion of customs, arts, culture and traditions that have noble values that are adhiluhung. Customs, arts, culture and traditions that have their own uniqueness and uniqueness in each Adat Village are fortified with traditional village legal products called Awig-Awig Adat Village and pararem as the implementation rules. This customary law product can fortify the existence of indigenous villages from the negative effects of globalization and carry out efforts to develop the potential of indigenous villages, preservation of Balinese culture and empowerment of Balinese people. Awig-Awig is a rule made by the Adat and / or Banjar Adat villages that apply to Krama Adat, Krama Tamiu, and Tamiu villages. Whereas Pararem is a regulation / decision of the Paruman of Indigenous Villages as the implementation of Awig-Awig or regulating new matters and / or settling customary / speech cases in the Customary Village (Bali Provincial Regulation Number 4 of 2019).

Community empowerment carried out by the Adat Village together with the government with the support of customary law products will be very effective in its implementation, because the provisions of customary law are highly obeyed by its citizens because they contain the value of local wisdom. Increasing the level of education of children by reducing the number of dropouts and encouraging school-age children to continue their education to a minimum level of secondary education, if it is linked to social capital in an adat village, it will be very effective. Customary law products in the form of awig-awig adat and pararem villages which are special norms of adat villages with high adherence to customary villagers, then the 12 -year compulsory education program will be achieved well. This becomes very important, if the implementation of the 12 year compulsory education program becomes part and content of awig-awig or pararem in each of the traditional villages in Bali. Because awig-awig and pararem are made based on paruman traditional village manners in managing interactions and community life procedures accompanied by strict sanctions, more real and can be implemented properly according to the norms and noble values that exist in traditional villages. The Adat village can regulate in the pararem the traditional village regarding the obligation of school-age children to continue their education, as an effort to prevent dropouts to improve the quality of human resources, because the level of education is positively correlated with income and welfare of the community.

\section{CONCLUSION}

The level of education has a positive effect on economic growth for the welfare of society. In improving the welfare of the community, increasing access to education in accordance with the 12-year compulsory education program must continue to be done, including reducing the dropout rate. The achievement of the results of educational development is influenced by the family environment, the school environment and the community environment. The structure of community life in Bali, especially the life arrangements of indigenous peoples, Desa Adat has a very important and dominant role in influencing community activities. In traditional villages the three main elements of social capital have a very strong influence. Trust (trust) and community belief contained in the norms in the form of awig-awig and pararem become the basis of people's lives. Reciprocal relationships in the form of cooperation, giving and receiving, mutual assistance and social interaction networks within the sphere of trust and reciprocal relationships within the community are still steady in Bali. With the position, authority and existence of traditional villages that have very strong social capital, namely awig-awig and pararem in each customary village, supported by an environment of people who have high obedience and trust, then Desa Adat has a role and influence on improving children's education. Implementation of educational programs in improving access and quality of education and reducing the number of dropouts, synergy between the local government and traditional villages is needed, so that with a higher level of community education the welfare of the community also increases. 


\section{REFERENCES}

1. 2014. Undang-Undang Nomor 6 Tahun 2014 tentang Desa.

2. Ajzen, I. 1991. The theory of planned behavior. Organizational Behavior and Human Decision Processes, 50, 179-211.

3. Ahmadi, A and Uhbiyati, N. 2001. Ilmu Pendidikan, Rineka Cipta, Jakarta.

4. Abu Ahmadi, Abu. 2009. Psikologi Sosial, Rineka Cipta, Jakarta.

5. Asshiddiqie, J. 2010. Konstitusi masyarakat desa (piagam tanggungjawab and hak asasi warga desa) (online). Tersedia: (http://jimly.com/makalah/namafile/176/Kinstitusi Masyarakat Desa.pdf)

6. Ahmad. 2011. Pendidikan dasar pada anak, Trans Info Media, Jakarta.

7. Ajis, Olvrias Tenisa. 2012, Faktor-Faktor Penyebab Anak Putus Sekolah pada Tingkat SMA di Kelurahan Gedong Meneng Kecamatan Rajabasa Kota Namdar Lampung, Universitas Negeri Lampung.

8. Alghazo, Yazan. 2013. The Theory of Planned Behavior and Parental Involvement: A Theoretical Framework for Narrowing the Achievement Gaps, International Journal of Science and Research (IJSR) ISSN (Online): 2319-7064.

9. Bronfenbrenner, U. 1986. Ecology of the family as a context for human development: Research perspectives. Developmental Psychology, 22(6), 723-741.

10. Bintarto. 1989. Interaksi Desa Kota and Permasalahannya. Penerbit Ghalia Indonesia: Jakarta.

11. Badan Pusat Statistik. 2010 Jumlah Penduduk Indonesia and Komposisinya, Badan Pusat Statistik Propinsi Bali.

12. Blondal., Kristjana Stella. 2014. Student Disengagement and School Dropout: Parenting Practices as Context, Dissertation, Faculty of Education, University of Iceland.

13. Badan Pusat Statistik Provinsi Bali. 2019. Berita Resmi Statistik, https://bali.bps.go.id.

14. Coleman, James S. 1988. Social capital in the Creation of Human Capital, American Journal of Sociology 94: S95-S120.

15. Chiuri, L. W \& Kiumi, J. K. 2005. Economic of Education. Egerton University: Pangolin publishers. Nairobi

16. Djumhur and Surya, Moh.,1975. Bimbingan and Konseling di Sekolah, Cv. IImu, Bandung.

17. Dove, M. R. 1985. Peranan Kebudayaan Tradisional Indonesia dalam Modernisasi. Jakarta: Yayasan Obor Indonesia.

18. Doll, J. J., Eslami, Z \& Walters, L. 2013. Understanding Why Students Drop Out of High School, According to Their Own Reports: Are They Pushed or Pulled, or Do They Fall Out? A Comparative Analysis of Seven Nationally Representative Studies. Retrieved on $10^{\text {th }}$ November 2017 from http://www.journals .sagepub .com/doi/full/10.1177/21 58244013503834

19. Dewi, Ni Ayu Krisna. 2013, Analisis Faktor-Faktor Penyebab Anak Putus Sekolah Usia Pendidikan Dasar di Kecamatan Gerokgak Tahun 2012/2013, Universitas Pendidikan Ganesha, Singaraja.

20. Direktorat Jenderal Kebudayaan. 2018. Petunjuk Teknis Revitalisasi Desa Adat, Kementerian Pendidikan and Kebudayaan, Jakarta.

21. Farah, Mutiara, 2014, Faktor Penyebab Putus Sekolah and Dampak Negatifnya bagi Anak (Studi Kasus di Desa Kalisoro Kecamatan Tawangmangu Kabupaten Karanganyar), Universitas Muhammadyah Surakarta.

22. Goksen, F., Cemalcılar, Z. ve Gurlesel, C. 2006. Turkiye'de ilkogretim okullarında okul terk ve izlenmesi ile önlenmesine yonelik politikalar. http://erg.sabanciuniv.edu/sites/erg. sabanciuniv.edu/files/ adresinden edinilmistir.

23. Gede. I Gusti Ketut, I Wayan Wirga, I Gede Iwan Suryadi. 2016. Model Pemberdayaan Desa Adat pada Dua Desa Tujuan Wisata di Bali (Studi Komparatif Desa Adat Intaran and Kuta), Jurusan Administrasi Niaga Politeknik Negeri Bali, Jurnal Bisnis and Kewirausahaan Vol. 12 No. 1 Maret 2016. 
24. Kitavi M. J. 2005. An investigation of factors influencing Performance in KCPE examination in, Kathonzweni Division Makueni District; Unpublished M.E.D Thesis, U.O.N. KNEC (2003), KCSE candidates" performance annual report 2003, KNEC regulations and syllabus for KCSE.

25. Maggi, Stefania, 2005. Knowledge Network For Early Child Development. Analytic and Strategic Review Paper: International Perspectives on Early Child Development, World Health Organization's, Commission on the Social Determinants of Health.

26. Putnam, R. 1995. Bowling alone: America's declining social capital, Journal of Democracy, 6(1), 65-78.

27. Rumberger RW. 2001. "Dropouts in America: How Severe is the Problem? What Do We Know about Intervention and Prevention?", Paper prepared for the Conference, January 13, 2001, Harvard University.

28. Romero, Mary Eunice. 2010. How Should Young Indigenous Children Be Prepared for Learning? A Vision of Early Childhood Education for Indigenous Children, Journal of American Indian Education, 49 (1 \& 2), 2010 (in press).

29. Rasmy, Mohamed Irshana., Sivapalan Selvadurai \& Junaenah Sulehan, 2017. Social Environmental Determinants of Student Dropout in the Plantation Settlement, Geografia Online $^{\mathrm{TM}}$ Malaysian Journal of Society and Space 13 issue 2 (54-64), Universiti Kebangsaan Malaysia Bangi, Malaysia.

30. Shaw, C. 1942. Juvenile delinquency and urban areas.University of Chicago Press.

31. Smith, Mark H., Lionel J. Beaulieu, and Glenn D.Israel. 1992. Effects of Human Capital and Social Capital on Dropping Out of High School in the South, Journal of Research in Rural Education, Winter 1992, Vol. 8, \#1, pp. 75-87, University of Florida.

32. Syahra, Rusydi. 2003. Modal Sosial: Konsep and Aplikasi, Jurnal Masyarakat and Budaya, Volume 5 No. 1 Tahun 2003.

33. Surpha, I Wayan. 2004. Eksistensi Desa Adat and Desa Dinas di Bali, Pustaka Bali Post, Denpasar.

34. Serinah, I Wayan. 2006. Efektivitas Pelaksanaan Program BOS Dalam Penuntasan Wajib Belajar Pendidikan Dasar di Kabupaten Karangasem, Tesis, Universitas Udayana, Denpasar.

35. Soetomo. 2006. Strategi-strategi Pembangunan Masyarakat, Pustaka Pelajar, Yogyakarta.

36. Somad, Permanarian. 2013. Teori Ekologi sebagai Dasar Pengembangan Keterampilan Komunikasi Siswa Tunarungu Usia Pra-Sekolah, Jurnal Asesmen and Intervensi Anak Berkebutuhan Khusus, Universitas Pendidikan Indonesia, Jakarta.

37. Sudibia, I Ketut., Ni Nyoman Yuliarmi, Desak Ketut Sintaasih. 2016. Pemberdayaan Masyarakat Desa Adat Dalam mendukung Eksistensi Lembaga Perkreditan Desa di Provinsi Bali, Universtitas Udayana, Denpasar.

38. Suarmanayasa, I Nengah., Sudibia I Ketut, Suartana, I Wayan. Suyana Utama I Made,. 2016. Effect of Social Capital, Community Participation, and Performance of Indigenous Community Financial Institutions for Rural Development in the Province of Bali, Journal of Economics and Sustainable Development, ISSN 2222-1700 (Paper) ISSN 2222-2855 (Online) Vol.7, No.20, 2016.

39. Sumunar. D.R.S., 2017. Masyarakat Desa Adat Tenganan Pegringsingan, Jurnal Penelitian Humaniora, Vol. 22, No. 2, Oktober 2017: 111-124

40. Todaro. 1983. Pembangunan Ekonomi di Dunia Ketiga, Ghalia Indonesia, Jakarta.

41. 2004. Ekonomi Pembangunan. Yogyakarta: BPFE Universitas Gadjah Mada, Yogyakarta.

42. UNESCO/UNICEF/MoEST. 2001. Report on Monitoring Achievement, A survey project. Ministry of Education: Botswana.

43. Voydanoff, Patricia. 2001. Conceptualizing community in the context of work and family. Community, Work and Family 4 (2): 133-156.

44. Wira Sakti, Nufrasansa. 2018. Indonesia Sambut Positif Human Capital Index Bank Dunia, Siaran Pers Menteri Keuangan, Biro Komunikasi and Layanan Informasi Setjen Kementerian Keuangan, Jakarta. 